Acta vet. scand. $1967,8,369-389$.

From the Department of Animal Husbandry and Genetics and the Department of Pathology, Veterinary College of Norway, Oslo.

\title{
THE EFFECT OF VARIOUS LEVELS \\ OF CALCIUM, PHOSPHORUS AND VITAMIN D \\ IN THE FEED FOR GROWING PIGS \\ WITH SPECIAL REFERENCE TO ATROPHIC RHINITIS
}

By

Börge Baustad, Jon Teige jr. and Sverre Tollersrud

Most of the experiments to determine the requirements of calcium and phosphorus in pigs of age 2 to 9 weeks, have shown that optimal weight gain and feed conversion are obtained by giving $0.4 \%$ of calcium in the feed with a calcium-phosphorus ratio of about 1 . An increase of the calcium and phosphorus contents to 0.8 and $0.6 \%$, respectively, has resulted in an increased calcification and breaking strength of the bones, without any significant influence on weight gain and feed conversion (Miller et al. 1962, 1964a, b, Zimmerman et al. 1963, Rutledge et al. 1961).

Other authors, however, (Combs et al. 1962, Combs \& Wallace 1962) have stated that by increasing the calcium content from 0.40 to $0.88 \%$ an approximate linear decrase in daily weight gain and a decreased feed conversion were obtained. No effect was observed on weight gain and feed conversion by changing the phosphorus content from 0.24 to $0.77 \%$. Increased amounts of phosphorus in the diet resulted in higher ash content of the bones.

Chapman et al. (1962) have studied the calcium and phosphorus requirements of pigs weighing 12 to $90 \mathrm{~kg}$. Highest daily weight gain and maximal breaking strength of the bones were obtained by $0.8 \%$ of calcium and $0.6 \%$ of phosphorus in the 
feed up to $45 \mathrm{~kg}$. During the whole period from 12 to $90 \mathrm{~kg}$ best results were obtained by $0.7 \%$ of calcium and $0.5 \%$ of phosphorus.

Pigs of 6 to $90 \mathrm{~kg}$ (Brown et al. 1966) achieved somewhat higher daily weight again when the calcium content of the diet was increased to 1.20 or $1.00 \%$ and phosphorus to 1.00 or $0.80 \%$, respectively, while the feed conversion efficiency was best at $0.80 \%$ calcium and $0.60 \%$ phosphorus. In view of their investigation on atrophic rhinitis, they recommend $1.20 \%$ of calcium and $1.00 \%$ of phosphorus in the feed for growing pigs. They presume that the reduced growth rate and feed efficiency reported by other investigators are caused by a decreased palatibility or a deficiency or an unbalance of one or more trace minerals (e.g. zinc) in the feed.

According to Norwegian investigators $0.6-0.8 \%$ of calcium and $0.55-0.6 \%$ of phosphorus are recommended for growing pigs up to $50 \mathrm{~kg}$ live-weight (Vadla et al. 1957).

The requirement of vitamin $D$ for young pigs has been determined by Miller et al. (1964c, 1965). They found that the requirement did not exceed 100 i.u. vitamin $D_{2}$ per $\mathrm{kg}$ feed on a semisynthetic diet with casein as protein source and containing $0.8 \%$ of calcium and $0.6 \%$ of phosphorus. If casein was replaced by soybean meal, at least 500 i.u. were needed for an optimal weight gain and a normal mineral balance.

Other investigators (Combs et al. 1966a) have been unable to demonstrate differences in daily weight gain, feed conversion and bone ash content between vitamin $\mathrm{D}$ supplemented animals and controls. An increased absorption of calcium was demonstrated after vitamin D supply to a diet containing about $0.5 \%$ of calcium and phosphorus. This experiment lasted for 6 to 7 weeks.

Pedersen (1940) observed no effects of supplements of vitamin $\mathrm{D}$ to slaughter pigs on diets containing optimal amounts of calcium and phosphorus.

The lesions found in the skeleton by a relative or absolute deficiency or excess of either of these three elements are what is called the classical osteodystrophies, viz. rickets, osteomalacia and osteodystrophia fibrosa (Jubb \& Kennedy 1963).

In atrophic rhinitis in swine pathological changes of the snout are usually found in the bones as well as in the soft tissues.

The etiology of atrophic rhinitis has hitherto been obscure. Several authors have maintained that the atrophic rhinitis is of 
an infectious character (Review by Switzer 1964, Duncan et al. 1966).

Others have asserted that atrophic rhinitis is caused by nutritional deficiencies. Bendixen (1957) is of opinion that the primary cause of atrophic rhinitis is a deficiency of the vitamins $A$ and $D$ besides lack of calcium in the nutrition of the pregnant sow. Larsen (1962) claims that atrophic rhinitis is caused by a deficiency of animal protein in the feed of the mother sows.

In a recent experiment Brown et al. have produced atrophic rhinitis in pigs either by increasing the phosphorus or by decreasing the calcium content of the diet to the calcium-phosphorus ratios $1: 2$ or $1: 4$. All the pigs on these diets developed atrophic rhinitis. Control animals on a diet with the calciumphosphorus contents recommended by $N R C$ (1964), calcium $0.8 \%$ and phosphorus $0.6 \%$, were free from macroscopic atrophic rhinitis, but showed microscopic signs of the disease. By increasing the calcium content to 1.20 and phosphorus to $1.00 \%$ of the feed, none of the animals developed atrophic rhinitis. Haaranen (1966) could prevent atrophic rhinitis in a herd by increasing the calcium content of the starter feed from $0.6 \%$ to above $1 \%$.

Björklund (1958) and Ludvigsen (1960) suggest that atrophic rhinitis is caused by disturbances in the mechanism of adaptation and that infections only play an indirect part.

Jonsson (1966) has found that nasal alterations in pigs of Danish Landrace have a heritability of 0.2 .

The present investigation was carried out as an attempt to produce atrophic rhinitis in pigs experimentally by administering different levels of calcium, phosphorus and vitamin $D$ in the diet. Further, it was deemed to see how the various diets influenced the rate of growth and health of the pigs.

\section{MATERIAL AND METHODS}

Thirty-two pigs of Norwegian Landrace were used in the experiment. The pigs were brought to the Experimental Farm Wöyen from a herd in which atrophic rhinitis had not occurred for the last 6 years. Prior to the start of the experiment the pens were thoroughly cleaned and disinfected and had been vacant for one month. The pigs were weaned at an age of 4 to 5 weeks and given a ration of dry feed and sow milk substituent for about 14 
days. At the beginning of the experiment the average weight of the pigs was $9 \mathrm{~kg}$. The duration of the experiment was 124 days.

The pigs were individually handfed twice daily. The rations were restricted to the amounts eaten by most of the animals. The pigs were divided into 8 groups with 4 animals in each, the groups being as equal as possible in respect of weight and sex.

The contents of calcium, phosphorus and vitamin $D$ in the ration of the different groups are given in Table 1.

T a b l e 1. Calcium, phosphorus and vitamin $D_{3}$ in the ration of the different groups.

\begin{tabular}{|c|c|c|c|}
\hline Group & $\begin{array}{c}\text { Calcium } \\
\%\end{array}$ & $\begin{array}{c}\text { Phosphorus } \\
0 \%\end{array}$ & $\begin{array}{l}\text { Vitamin } D_{3} \text { i.u } \\
\text { per kg food }\end{array}$ \\
\hline $\mathrm{I}_{0}$ & 0.70 & 0.60 & 0 \\
\hline $\mathrm{I}_{\mathrm{D}}$ & 0.70 & 0.60 & 300 \\
\hline $\mathrm{II}_{0}$ & 0.30 & 0.60 & 0 \\
\hline $\mathrm{II}_{\mathrm{D}}^{0}$ & 0.30 & 0.60 & 300 \\
\hline $\mathrm{III}_{0}^{\mathrm{D}}$ & 0.70 & 1.40 & 0 \\
\hline III $_{\mathbf{D}}$ & 0.70 & 1.40 & 300 \\
\hline $\mathrm{IV}_{0}^{\mathrm{D}}$ & 0.35 & 1.40 & 0 \\
\hline $\mathrm{IV}_{\mathrm{D}}$ & 0.35 & 1.40 & 300 \\
\hline
\end{tabular}

The basal diet consisted of ground barley, soybean meal, a mineral mixture and supplements of the vitamins $A, E$ and $B_{2}$. The detailed composition of the diet is given in Table 2.

T a b l e 2. Composition of the diet in the groups I, II, III and IV.

\begin{tabular}{lrccc}
\hline & Group I & Group II & Group III & Group IV \\
\hline Ground barley & 74.92 & 75.70 & 70.50 & 71.14 \\
Soybean meal & 22.00 & 22.00 & 23.00 & 22.50 \\
Mineral mixture & 1.00 & 1.00 & 1.00 & 1.00 \\
$\begin{array}{l}\text { Dicalciumphosphate } \\
\quad \mathrm{CaHPO}_{4} \cdot 2 \mathrm{H}_{2} \mathrm{O}\end{array}$ & 1.33 & 0.90 & 2.62 & 1.12 \\
$\begin{array}{l}\text { Calciumcarbonate CaCO } \\
\text { Monosodiumphosphate }\end{array}$ & 0.75 & - & - & - \\
$\quad \mathrm{NaH}_{2} \mathrm{PO}_{4} \cdot 2 \mathrm{H}_{2} \mathrm{O}$ & - & 0.40 & 2.88 & 4.24 \\
\hline
\end{tabular}

The mineral mixture had the following composition per 1,000 g: Sodium chloride $566.2 \mathrm{~g}$, magnesium carbonate $400.0 \mathrm{~g}$, ferrous sulfate $13.5 \mathrm{~g}$, manganous sulfate $11.0 \mathrm{~g}$, cupric sulfate $2.5 \mathrm{~g}$, cobalt chloride $0.1 \mathrm{~g}$, potassium iodide $0.2 \mathrm{~g}$, zinc oxide $6.5 \mathrm{~g}$.

In addition $100 \mathrm{mg}$ riboflavin and 200,000 i.u. vitamin $A$ were given per $100 \mathrm{~kg}$ feed. From the eighth week of the experiment $100 \mathrm{mg}$ $\alpha$-tocopherol was given per animal per day. 
Group I was given the calcium and phosphorus amounts considered optimal (Vadla et al. 1957). In the groups II and III the calcium-phosphorus ratio was $1: 2$ and in group IV 1:4. For all D-groups a supplement of 300 i.u. vitamin $D_{3}$ was given per $\mathrm{kg}$ feed. The 0-groups did not receive extra vitamin D. Every second week the pigs were weighed and blood samples taken from the anterior vena cava. The following components were determined in blood serum: calcium, inorganic phosphorus and alkaline phosphatase.

Calcium was determined by titration in EEL-Titrator with EGTA in the presence of ZnEGTA and with Zincon as indicator (a micromodification by $\mathrm{Halse}$ (personal communication) based on the principle described by Ringbom et al. (1958)).

Inorganic phosphorus in serum was determined by a modification (Zeiss-Opton 1951) of the method of Fiske \& Subbarow (1925). Alkaline phosphatase was determined according to Bessey et al. (1946).

After the pigs had died or were killed, the snout and a rib were subjected to histological examination. For comparison histological examination of the snout from some cases of spontaneous atrophic rhinitis was performed.

Tissue specimens for histological examination were taken from a cross-section of the snout at the first premolar teeth and from a rib transverse to the epiphyseal line. The slices were fixed in formaline, demineralized in formic acid-sodium citrate, embedded in paraffin and stained with hematoxylin-eosin and van Gieson stain.

The ash content of the third and fourth metacarpal bones of the right foreleg was determined according to Pedersen (1940), and the content of calcium and phosphorus in the ash determined. The cited figures from the analyses of the bones are the average values for the two metacarpal bones.

The statistical calculations were performed by means of Student's t-test.

\section{RESULTS}

\section{Clinical examination}

After about one month of experiment tremors and convulsions were seen in most of the pigs in the groups $\mathrm{II}_{0}, \mathrm{III}_{0}$ and $\mathrm{IV}_{0}$. The convulsions appeared most frequently when the pigs were distur- 
bed or excited, especially at feeding time, but also when they were handled for blood sampling or weighing.

After 36 days on the experimental diet one pig in group $\mathrm{IV}_{0}$ died, after 41 days one in group $\mathrm{III}_{0}$, after 43 days one in group $\mathrm{II}_{0}$, after 44 days one in group $\mathrm{IV}_{0}$ and after 55 days one pig in group III $_{D}$ (Table 5). All these pigs died after having shown severe tonic and clonic convulsions one or more times prior to death.

One pig in group III $_{D}$ died on the 68th day after a period of stunting. Post-mortem examination showed liver dystrophy and myocardial degeneration.

After about one and a half month distinct signs of rickets appeared in most of the surviving pigs in the groups $\mathrm{II}_{0}, \mathrm{III}_{0}$ and $\mathrm{IV}_{0}$. Especially in group $\mathrm{II}_{0}$ the symptoms were severe. The joints became enlarged and swollen, the pastern joints being most affected, besides the carpal and tarsal joints. The bones of the extremities were deformed, resulting in bowed legs and a stiff and painful gait. Two of the pigs in group $\mathrm{II}_{0}$ were killed on the 75 th day as they could hardly rise. The last pig in group $\mathrm{II}_{0}$, one in group $\mathrm{III}_{0}$ and the two last pigs in group $\mathrm{IV}_{0}$ were killed on the 118th day. They were then in a very bad condition.

During the first two and a half months there was no distinct clinical difference between the pigs in group $I_{0}$ and $I_{D}$, but after about 80 days symptoms of rickets occurred in the pigs in group $\mathrm{I}_{0}$. Muscular tremors appeared, and the gait became more stilty. The last month the pigs in group $I_{0}$ gained less weight than the corresponding pigs in group $\mathrm{I}_{\mathrm{D}}$.

None of the pigs had clinical signs of atrophic rhinitis. There were no snout deformations and no sneezing.

\section{Weight gain and feed conversion}

The weight gain was extremely low in most of the pigs in the groups $\mathrm{II}_{0}, \mathrm{III}_{0}$ and $\mathrm{IV}_{0}$. As the pigs in these groups died or were killed at different stages of the experiment, it is difficult to compare the daily weight gain in these groups with the groups which survived the whole experiment.

Daily weight gain and feed conversion in the groups $\mathrm{I}_{0}, \mathrm{I}_{\mathrm{D}}, \mathrm{II}_{\mathrm{D}}$, III $_{D}$ and IV $_{D}$ are given in Table 3.

The weight gain in the groups $I_{D}$ and $I_{D}$ is significantly greater than in the groups $I_{0}(P<0.05)$ and $\operatorname{IV}_{D}(P<0.01)$. 
- Calcium in serum, mg pr $100 \mathrm{ml}$.

-.-- Alkaline phosphatase in serum, Bessey - Lowry units
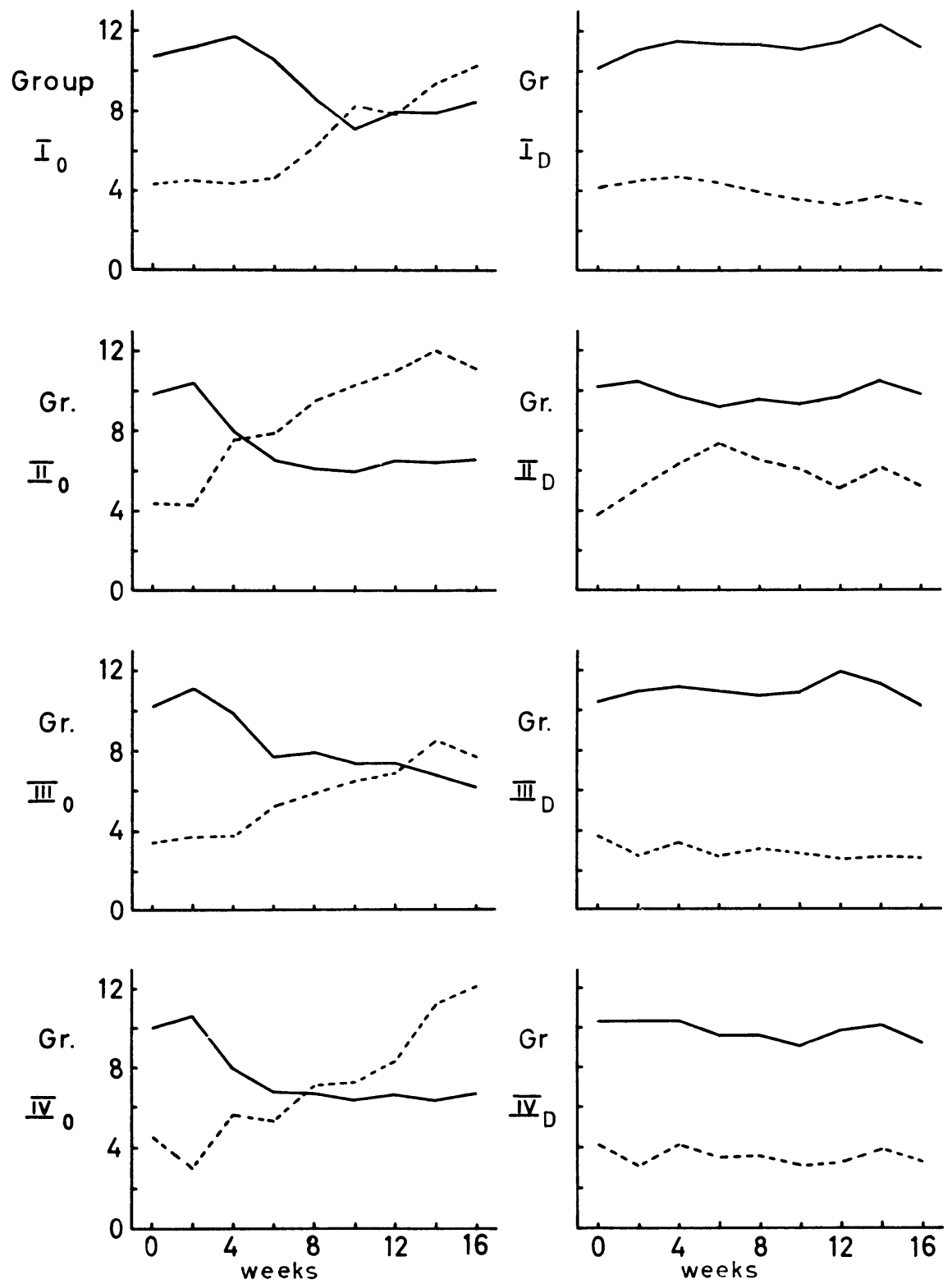

F i g u r e 1. Calcium and alkaline phosphatase in serum. Mean values for all surviving pigs in the groups. 
T a b l e 3. Daily weight gain and feed conversion in the groups $I_{0}, I_{D}$, $\mathrm{II}_{\mathrm{D}}, \mathrm{III}_{\mathrm{D}}$ and $\mathrm{IV}_{\mathrm{D}}$.

\begin{tabular}{ccc}
\hline Group & Daily weight gain, g & kg feed pr. kg weight gain \\
\hline $\mathrm{I}_{0}$ & 393 & 3.09 \\
$\mathrm{I}_{\mathrm{D}}$ & 457 & 2.81 \\
$\mathrm{II}_{\mathrm{D}}$ & 441 & 2.93 \\
$\mathrm{III}_{\mathrm{D}}$ & 419 & 2.92 \\
$\mathrm{IV}_{\mathrm{D}}$ & 339 & 3.14 \\
\hline
\end{tabular}

Calcium, phosphorus and alkaline phosphatase in serum

Serum calcium and alkaline phosphatase values in the different groups are given in Fig. 1.

In all groups without vitamin D supplements, a decrease in serum calcium was observed, rapidly followed by an increase in alkaline phosphatase. These alterations occurred after 2 to 4 weeks in the groups $\mathrm{II}_{0}, \mathrm{II}_{0}$ and $\mathrm{IV}_{0}$, and were most pronounced in group $\mathrm{II}_{0}$. In group $\mathrm{I}_{0}$ the fall in serum calcium was seen after 6 to 8 weeks.

The groups receiving vitamin $\mathrm{D}$ maintained fairly constant serum calcium and alkaline phosphatase levels. In the groups $\mathrm{II}_{\mathrm{D}}$ and $\mathrm{IV}_{\mathrm{D}}$ a slight decrease in serum calcium was seen after 4 weeks, in group $\mathrm{II}_{D}$ a rise in alkaline phosphatase was noted from the second week.

The content of inorganic phosphorus in serum was fairly constant in all the groups during the whole experiment, about $10 \mathrm{mg}$ per $100 \mathrm{ml}$, with a tendency to decrease in the groups $I_{0}$ and $\mathrm{II}_{0}$ towards the end of the experiment. In group $\mathrm{IV}_{\mathrm{D}}$ the inorganic phosphorus level was somewhat higher than in the other groups at the end of the experiment, about $13 \mathrm{mg}$ per $100 \mathrm{ml}$.

T a b l e 4. Bone ash, and calcium and phosphorus in ash of the third and fourth metacarpal bones of the right foreleg in groups $\mathrm{I}_{0}, \mathrm{I}_{\mathrm{D}}, \mathrm{II}_{\mathrm{D}}$,

\begin{tabular}{|c|c|c|c|}
\hline Group & $\begin{array}{c}\text { Ash } \\
0 \%\end{array}$ & $\underset{0 \%}{\text { Calcium in ash }}$ & $\begin{array}{c}\text { Phosphorus in ash } \\
0 \%\end{array}$ \\
\hline $\mathrm{I}_{0}$ & 52.6 & 38.7 & 18.7 \\
\hline $\mathrm{I}_{\mathrm{D}}$ & 57.6 & 38.6 & 18.5 \\
\hline $\mathrm{II}_{\mathrm{D}}$ & 55.0 & 38.4 & 18.8 \\
\hline III $_{D}$ & 56.2 & 38.4 & 18.5 \\
\hline $\mathrm{IV}_{\mathrm{D}}$ & 55.6 & 38.4 & 18.6 \\
\hline
\end{tabular}




\section{Bone analyses}

Determinations of the ash content of bones, and calcium and phosphorus in the bone ash, were carried out in all the pigs which survived the experiment. The average values for the groups $I_{0}, I_{D}$, $\mathrm{II}_{\mathrm{D}}, \mathrm{III}_{\mathrm{D}}$ and $\mathrm{IV}_{\mathrm{D}}$ are given in Table 4.

The ash percentage was highest in group $I_{D}$ and was significantly higher than in groups $\mathrm{I}_{0}(\mathrm{P}<0.001), \mathrm{II}_{\mathrm{D}}(\mathrm{P}<0.01)$, III $_{D}$ and $\operatorname{IV}_{D}(P<0.05)$. The ash percentage in group $I_{0}$ was significantly lower than in groups $\mathrm{II}_{D}(P<0.05), \mathrm{III}_{D}$ and $\mathrm{IV}_{\mathrm{D}}$ $(P<0.01)$. The calcium and phosphorus contents in ash were at the same level in all groups.

\section{Post-mortem examinations}

Gross lesions. In two of the pigs in the experiment a slightly increased interspace between the upper and lower turbinates was

T a ble 5. Histological examination of the turbinates and ribs.

\begin{tabular}{|c|c|c|c|c|c|c|c|c|c|}
\hline Group & $\begin{array}{l}\text { Pig } \\
\text { no. }\end{array}$ & $\begin{array}{c}\text { Number } \\
\text { of days in } \\
\text { experiment }\end{array}$ & $\begin{array}{c}\text { Tur- } \\
\text { bi- } \\
\text { nates }\end{array}$ & Ribs & Group & $\begin{array}{l}\text { Pig } \\
\text { no. }\end{array}$ & $\begin{array}{c}\text { Number } \\
\text { of days in } \\
\text { experiment }\end{array}$ & $\begin{array}{c}\text { Tur- } \\
\text { bi- } \\
\text { nates }\end{array}$ & Ribs \\
\hline \multirow[t]{4}{*}{$\mathrm{I}_{0}$} & 868 & 124 & 2 & 1 & \multirow[t]{4}{*}{$I_{D}$} & 860 & 124 & 0 & 0 \\
\hline & 869 & 124 & 2 & 2 & & 874 & 124 & 0 & 0 \\
\hline & 907 & 124 & 3 & 3 & & 905 & 124 & 2 & 0 \\
\hline & 910 & 124 & 4 & 3 & & 906 & 124 & 1 & 0 \\
\hline \multirow[t]{4}{*}{$\mathrm{II}_{0}$} & 871 & 75 & 2 & 5 & \multirow[t]{4}{*}{$\mathrm{II}_{\mathrm{D}}$} & 862 & 124 & 3 & 0 \\
\hline & 908 & 75 & - & 4 & & 870 & 124 & 3 & 1 \\
\hline & 861 & 43 & 4 & 3 & & 915 & 124 & 2 & 1 \\
\hline & 912 & 118 & 2 & 3 & & 917 & 124 & 2 & 0 \\
\hline \multirow[t]{4}{*}{$\mathrm{III}_{0}$} & 914 & 41 & 3 & - & \multirow[t]{4}{*}{ IIII $_{D}$} & 895 & 68 & 1 & 0 \\
\hline & 873 & 55 & 2 & 3 & & 864 & 124 & 2 & 1 \\
\hline & 893 & 124 & 2 & 1 & & 872 & 124 & 0 & 0 \\
\hline & 866 & 118 & 2 & 3 & & 911 & 124 & 0 & - \\
\hline \multirow[t]{4}{*}{$I V_{0}$} & 882 & 36 & 2 & 1 & \multirow[t]{4}{*}{$I V_{D}$} & 863 & 124 & 1 & 0 \\
\hline & 865 & 44 & 2 & 3 & & 878 & 124 & 3 & 1 \\
\hline & 909 & 118 & 2 & 3 & & 902 & 124 & 2 & 0 \\
\hline & 876 & 118 & 2 & 4 & & 916 & 124 & 2 & 1 \\
\hline
\end{tabular}

Symbols for degree of lesions:

Turbinates: $0=$ No pathological changes.

$1-5=$ Small to high-grade resorption of the bone tissue in the trabeculae.

Ribs: $\quad 0=$ No pathological changes.

$1-5=$ Small to high-grade disturbance of the endochondral ossification. 


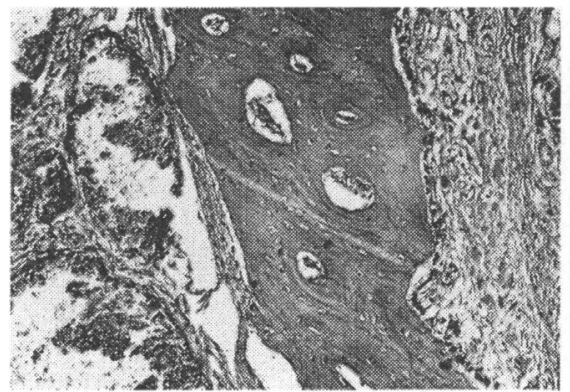

Figure 2. Turbinate from pig no. 874, group $I_{D}(16 \times$, van Gieson stain). The trabeculae have a regular surface and are well developed.

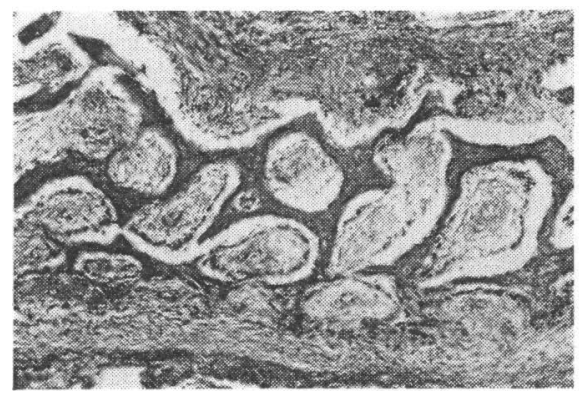

Figure 4. Turbinate from pig no. 864, group $\mathrm{III}_{D}(16 \times$, van Gieson stain). A moderate fibril production in the confluent marrow cavities. On the surface of the poorly developed trabeculae a small proliferation of osteoblasts.

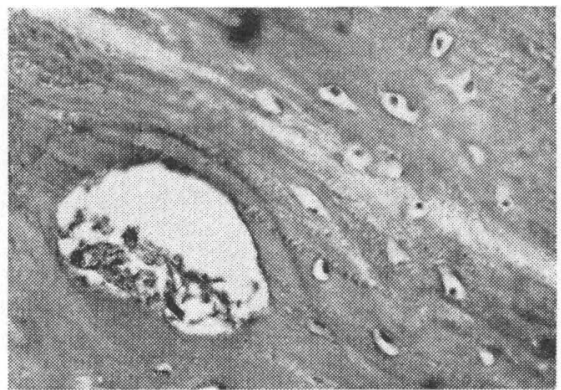

Figure 3. Turbinate from pig no. 874, group $I_{D}(64 \times$, van Gieson stain). Loosely woven connective tissue in the marrow cavity and a few osteocytic lacunae in the trabeculae.

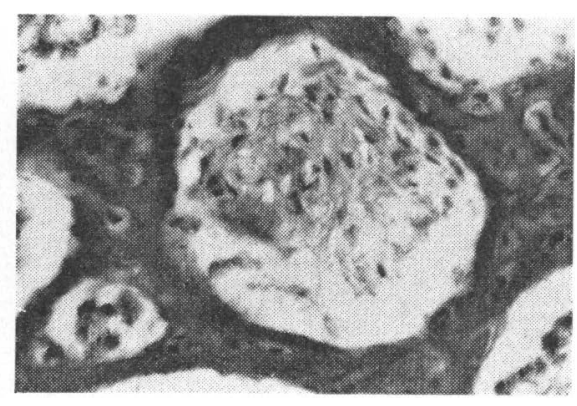

Figure 5. Turbinate from pig no. 864 , group III $_{D}(64 \times$, van Gieson stain). Deeply situated osteocytes with an incipient clarifying zone. The marrow cavity is more abundant in cells and fibrils than normal. 


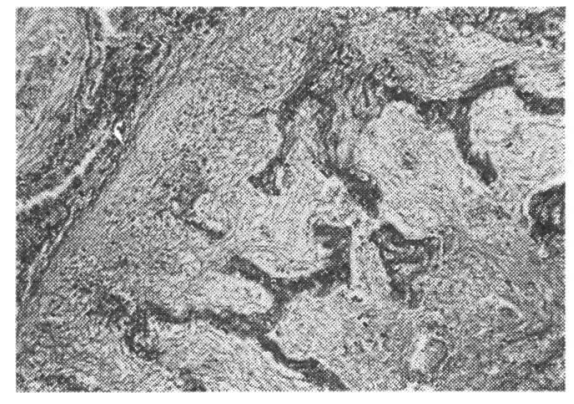

Figure 6. Turbinate from pig no. 910, group $I_{0}(16 \times$, van Gieson stain). Badly coherent trabeculae with an uneven, lacerated surface. In the marrow cavities an abundant fibril production.

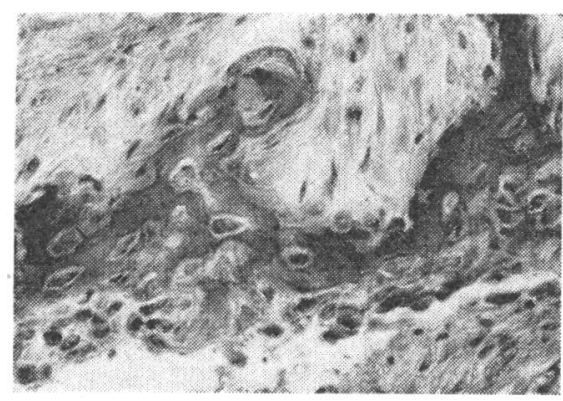

F i g u re 8. Turbinate from a case of spontaneous atrophic rhinitis. J. no. A 338/66 (64 $\times$, van Gieson stain). A layer rich in cells lining the trabeculae, which contain some osteocytic lacunae. The diameter of the bony core reduced.

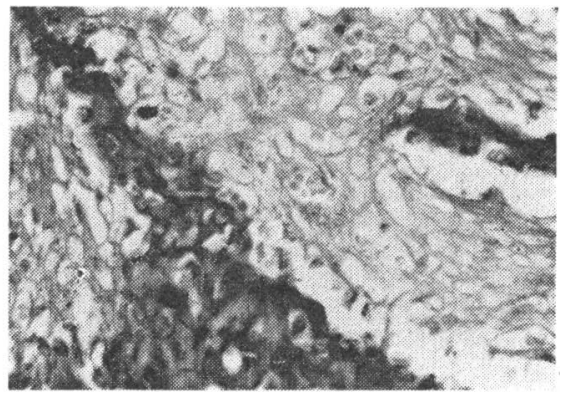

Figure 7. Turbinate from pig no. 910, group $I_{0}(64 \times$, van Gieson stain). Multiple osteocytic lacunae and some of these seem to be open to the surface of the trabeculae.

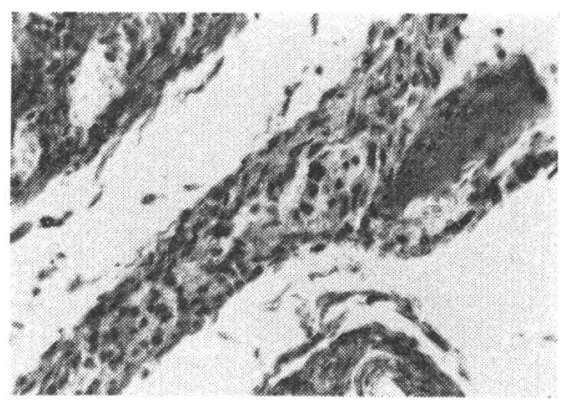

Fig u re 9. Turbinate from a case of spontaneous atrophic rhinitis. J. no. A 1853/66 (64 $\times$, van Gieson stain). Only small remnants of the bony core. The trabeculae replaced by a cord of very cell-rich connective tissue. 
seen (pig no. 910 in group $I_{0}$ and pig no. 895 in group $\mathrm{III}_{D}$ ). Otherwise no pathological changes appeared in the nose cavity.

Microscopic lesions. The microscopic lesions of the turbinates and ribs are summarized in Table 5.

Turbinates. A slight proliferation of osteoblasts was found in the bony core of the turbinates of some animals. The osteoblasts had the appearance of a single cell row lining the trabeculae. In a few cases an accumulation of osteoblasts under the periosteum was seen. In only one pig were osteoclasts observed in the bony core.

In the 0 -groups the general picture was that the bony core was wider than normal. The trabeculae, however, were slender with an insufficient coherence in several areas of the turbinates.

The surface of the trabeculae showed a rather uneven or lacerated appearance, and they frequently contained several osteocytic lacunae. The number of lacunae differed from one area of the turbinate to another.

In the marrow cavities some connective tissue formation appeared. This was most marked in the pigs which stayed until the experiment terminated.

In pig no. 907 in group $\mathrm{I}_{0}$ and no. 914 in group $\mathrm{III}_{0}$ a great number of osteocytic lacunae were observed. The coherence of the trabeculae was poor. This fact was even more pronounced in pig no. 910 in group $I_{0}$ and in pig no. 861 in group $\mathrm{II}_{0}$ where in some areas of the turbinates only remnants of the trabeculae were left, apparently arranged in a parallel pattern.

In the groups which were given the vitamin D supplement the width of the bony core was not increased. The pigs in the groups $\mathrm{I}_{D}$ and $\mathrm{III}_{\mathrm{D}}$ had strong trabeculae with a rather good coherence. Only in a few of these pigs could be observed an increased number of osteocytic lacunae and a reasonable degree of connective tissue formation in the marrow cavities. In the groups $\mathrm{II}_{\mathrm{D}}$ and $\mathrm{IV}_{\mathrm{D}}$ the pathological changes had the same degree of development as described for the 0-groups. All the pigs in these two groups had developed some connective tissue formation between the trabeculae.

Figs. 2 to 7 illustrate the histological character of the turbinates in pigs from the present experiment.

$R$ i b s. The columns of cartilage cells had an increased length in several pigs of the 0 -groups. The growing zone was often 
irregular with several islands of cartilage cells underneath. The calcification of the cartilage was insufficient, and there was a scanty vascularisation of the primary marrow cavities. The trabeculae with a cartilagenous core were poorly developed. The other trabeculae just beneath the growth zone were rather large, of irregular shape and frequently transversally oriented.

Between these trabeculae of osteoid tissue abundant formations of connective tissue and several osteoclasts were observed. In one pig, no. 871 in group $\mathrm{II}_{0}$, the pathological changes were very pronounced. Several large islands of cartilage cells, a great number of osieoclasts and an extensive formation of connective tissue could be seen.

Three pigs (no. 868 in group $\mathrm{II}_{0}$, no. 893 in group $\mathrm{III}_{0}$ and no. 882 in group $\mathrm{IV}_{0}$ ) showed only a slightly increased length of the columns of cartilage cells, and a few trabeculae with a cartilagenous core were developed.

In the groups receiving vitamin $D$ most of the pigs showed a normal histological character of the rib sections. In a few animals similar changes to those in the least affected in the 0 -groups were seen.

Turbinates from spontaneous cases of atrophic rhinitis. Fig. 8 illustrates the pathological changes in a case of spontaneous atrophic rhinitis. A layer rich in cells lines the trabeculae which contain some osteocytic lacunae. There is a certain atrophy of the bony core of the turbinates. Fig. 9 shows a case where the degree of atrophic rhinitis is more pronounced. A cord of very cell-rich connective tissue occupies the place of the trabeculae and only small remnants of the bony core are left. Histological examinations of other cases of spontaneous atrophic rhinitis revealed the same picture as shown in Figs. 8 and 9.

\section{DISCUSSION}

In the present experiment a clearcut effect was obtained with supplements of 300 i.u. vitamin D per $\mathrm{kg}$ feed. The results were most evident in the groups with an unfavorable calcium-phosphorus ratio. Most of the animals in the vitamin D deficient groups died in hypocalcemic convulsions or were killed after severe symptoms of rickets. The vitamin D deficiency in these groups was accompanied by a heavy fall in serum calcium as early as after 2 to 4 weeks of the experiment. This drop was 
rapidly followed by a rise in alkaline phosphatase. The clinical symptoms such as convulsions and rickets were observed after one month, while decreased weight gain appeared after about 6 weeks.

In group I on levels of calcium and phosphorus considered optimal, there was no difference between the pigs in the 0-group and the D-group during the first 6 weeks of the experiment. Then a marked decrease in serum calcium and a subsequent rise in alkaline phosphatase appeared in the pigs deficient in vitamin $D$. Clinical signs of deficiency were observed after two and a half months. The weight gain was equal in the two groups until the 12th week after which the 0 -group began to lag behind.

The varying rate of development of deficiency symptoms in the different groups may probably be explained by an increased demand of vitamin $D$ on an unfavorable calcium-phosphorus ratio or level.

The difference in retention of calcium and phosphorus between the groups is clearly reflected in the ash content of the bones. However, no significant difference in the contents of calcium and phosphorus in the ash was seen. This is in agreement with Pullar (1960) and indicates that the relations between minerals deposited in the bones of rachitic and normal animals are the same.

In humans with rickets a rise in serum alkaline phosphatase is a regular phenomenon (Abderhalden 1961). Alkaline phosphatase is, however, considered not to be of the same diagnostic importance in the domestic animals (Simesen 1963). In the present material a marked increase in alkaline phosphatase was seen simultaneously with or shortly after the decrease in serum calcium. Rickets was most pronounced in group $\mathrm{II}_{0}$, where the highest values of alkaline phosphatase were observed. In some of the animals that died in hypocalcemic convulsions a rise in alkaline phosphatase was seen in the previous blood sample. Also in group $\mathrm{II}_{\mathrm{D}}$ there was noted a rise in the alkaline phosphatase values in most of the blood samples, and as there was neither clinical nor histopathological sign of rickets, this rise is difficult to explain.

Histological considerations. Osteoclasia is the classical form of bone resorption. Ham (1957) characterizes the polynucleated osteoclasts as the specific type of cell in this relation. Another 
type of bone resorption, osteolysis, seems to-day to be the prevalent theory (Krook 1965). The osteolysis is characterized by resorption in the deeper layers of the bone. This phenomenon was first observed by Recklinghausen (1910, cited from Brown et al. 1966). He described deeply located, enlarged lacunae. The cells were also observed in normal bone, but were found to be much more numerous in rickets and osteomalacia. Majno \& Rouiller (1951) showed that alkaline phosphatase was present in the deeply located osteocytes and was suggested to be the main cause of the bone resorption. This was called pericytic osteolysis.

In all the 0-groups and in the groups fed on an unfavourable ratio of calcium and phosphorus a resorption of the bone tissue in the trabeculae was clearly seen. This resorption was not caused by osteoclasts, as such cells were found only in a single case. The described changes of the turbinates (Figs. 4 to 7 ) seem rather to be in accordance with what is characteristic for the pericytic osteolysis.

Connective tissue formation in the marrow cavities and a pronounced osteoclasia are the main characteristics of osteodystrophia fibrosa. In an experiment with horses performed by Belanger et al. (1965, cited from Brown et al.) to produce this disorder on a diet with an unfavourable calcium-phosphorus ratio, osteoclasts did not appear in great number until after 10 weeks. The osteoclasts seem to appear rather late in the progress of osteodystrophia fibrosa.

After 16 weeks the pigs developed some connective tissue formation between the trabeculae but no osteoclasia.

The histological examination of the ribs revealed a disturbance of the endochondral ossification in many of the pigs. This is considered to be an important, if not a specific, feature in rickets (Nieberle \& Cohrs 1962). Between the osteoid trabeculae located beneath the growing zone osteoclasts and some connective tissue could be observed. These alterations usually appear in rickets in domestic animals (Pallaske 1960). They show, however, great resemblance to osteodystrophia fibrosa.

The histological changes in the bony core of the turbinates in atrophic rhinitis are described by Schofield \& Jones (1950). A great number of osteoblasts were found under the periosteum and in pronounced cases the trabeculae were replaced by these cells. The investigators point out that the proliferation of osteoblasts is not prevented, but their ability to form bone is diminished. 
Björklund (1958) is of opinion that a disturbance in the bone formation occurs in atrophic rhinitis. He found the periosteum rich in cells, the majority being of an immature character. The osteoblasts assumed gradually a fibroblast-like appearance and the trabeculae were transformed into connective tissue with abundant small inactive cellular elements. Duncan et al. (1966) by experimental Bordetella bronchiseptica infection have found remnants of bone surrounded by numerous osteoblasts. At the same time a reduction in the size of the osseous core occurred.

The alterations of the turbinates in pigs suffering from atrophic rhinitis, which we observed, correspond closely to those described in the literature.

The histological examination of the turbinates from the experimental pigs showed a pericytic osteolysis and a connective tissue formation in several of the groups. The 0 -groups were characterized by an increased width of the bony core of the turbinates. In some areas osteoblasts were slightly more numerous than normal. Compared with spontaneous cases of atrophic rhinitis there was thus no entirely histological similarity.

Like Brown et al. we found an increased number of osteocytic lacunae in spontaneous atrophic rhinitis (Fig. 8).

The pericytic osteolysis observed in the experiment produced, however, no distinct atrophy of the turbinates. The results of the present experiment indicate that, besides the atrophic rhinitis itself, a pericytic osteolysis can develop as a consequence of an unfavourable proportion or deficiency of phosphorus, calcium or vitamin $\mathrm{D}$ in the diet.

The content of calcium, phosphorus and vitamin $D$ in practical feeding rations varies within wide limits. On diets consisting mainly of concentrates of vegetable origin, the supply of calcium can be insufficient. The calcium-phosphorus proportion will easily reach the same level as in group II and even as in group IV. The content of vitamin $D$ will be negligible without additional supply. Both in group $\mathrm{I}_{0}$, with an optimal level of calcium and phosphorus, and in group $\mathrm{II}_{\mathrm{D}}$ and $\mathrm{IV}_{\mathrm{D}}$ with sufficient vitamin $\mathrm{D}$ supply, the resorption of the bone tissue of the trabeculae was obvious. Based on these facts it is reasonable to suggest that the pericytic osteolysis may appear spontaneously also in pigs suffering from atrophic rhinitis. 


\section{CONCLUSIONS}

1. On a vitamin $D$ deficient diet growing pigs showed reduced weight gain and feed conversion efficiency. The ash content of the bones was reduced and clinical signs of rickets appeared even on a diet containing $0.7 \%$ of calcium and $0.6 \%$ of phosphorus.

2. Vitamin D deficiency resulted in a marked fall in serum calcium followed by an increase in serum alkaline phosphatase.

3. The content of calcium and phosphorus in the bone ash was found to be at the same level in rachitic and normal pigs.

4. The bone resorption of the turbinates in the groups deficient in vitamin $D$ and in the groups on an unfavorable calciumphosphorus ratio, seemed to be caused by pericytic osteolysis.

5. Pericytic osteolysis was also found in cases of spontaneous atrophic rhinitis in pigs outside the experiment.

6. Macroscopic or characteristic histological signs of atrophic rhinitis were not found in any of the experimental pigs.

\section{REFERENCES}

Abderhalden, R.: Clinical enzymology. Princeton, New Jersey 1961, $448 \mathrm{pp}$.

Belanger, L. F., T. Semba, S. Tolnai, D. H. Copp, L. Krook \& C. Gries: The two faces of resorption. Proc. 3rd Europ. Symp. Calcified Tissues. Davos 1965. (Cited from Brown et al. 1966).

Bendixen, $\boldsymbol{H}$. C.: Veterinære problemer $\mathrm{i}$ forbindelse med sygelige tilstande hos unge grise med særligt henblik på dystrofiske tilstande i svinets næsehule. Medlemsbl. danske Dyrlægeforen. 1957, 40, 93-120.

Bessey, D. A., O. H. Lowry \& M. J. Brock: A method for the rapid determination of alkaline phosphatase with five cubic millimeters of serum. J. biol. Chem. 1946, 164, 321-329.

Björklund, N. E.: Atrophic rhinitis of pigs. Diss., Stockholm 1958.

Brown, W. R., L. Krook \& W. G. Pond: Atrophic rhinitis in swine. Cornell Vet. 1966, 56, Suppl. 1.

Chapman, H. L., Jr., J. Kastelic, G. C. Ashton, P. G. Homeyer, C. Y. Roberts, D. V. Catron, V. W. Hays \& V. C. Speer: Calcium and phosphorus requirements of growing-finishing pigs. J. Animal Sci. 1962, 21, 112-118.

Combs, G. E., J. M. Vandepopuliere, H. D. Wallace \& M. Koger: Phosphorus requirement of young pigs. J. Animal Sci. 1962, 21, 3-8.

Combs, G. E. \& H. D. Wallace: Growth and digestibility studies with young pigs fed various levels and sources of calcium. J. Animal Sci. 1962, 21, 734-737. 
Combs, G. E., T. H. Berry, H. D. Wallace \& R. C. Crum Jr.: Influence of supplemental vitamin $D$ on gain, nutrient digestibility and tissue composition of young pigs. J. Animal Sci. 1966a, 25, $48-51$.

Combs, G. E., T. H. Berry, H. D. Wallace \& R. C. Crum Jr.: Levels and sources of vitamin $D$ for pigs fed diets containing varying quantities of calcium. J. Animal Sci. 1966b, 25, 827-830.

Duncan, J. R., R. F. Ross, W. P. Switzer \& F. K. Ramsey: Pathology of experimental Bordetella bronchiseptica infection in swine: Atrophic rhinitis. Amer. J. vet. Res. 1966, 27, 457-466.

Fiske, C. H. \& Y. Subbarow: The colorimetric determination of phosphorus. J. biol. Chem. 1925, 66, 375-400.

Haaranen, S.: Alkaalinen fosfataasi ja eräät veren kivenäiset aivastustautisioilla. Suom. Eläinlääk.-L. (Finsk Vet.-T.) 1966, 72, 467468.

Halse, K.: Personal communication.

Ham, A. W.: Histology. 3rd Ed. J. B. Lippincolt Company, Philadelphia, Montreal 1957, 894 pp.

Jonsson, P.: Næseforandringerne hos fors $\emptyset$ gssvinene på de faste svinefors $\varnothing$ gsstationer. Land $\varnothing$ konom. Fors $\varnothing$ gslab. efterårsm $\varnothing$ de 1966, $123-128$.

Jubb, K. V. F. \& P. E. Kennedy: Pathology of domestic animals. Academic Press, New York and London 1963, 1, $477 \mathrm{pp}$.

Krook, L.: Nyssjuka hos svin - etiologi, patogenes och profylax. Svensk Vet.-Tidn. 1965, 17, 548-554.

Larsen, $S .:$ Deformerende conchaatrofi hos ungsvin som følge af fejlaktigt ernæringsmiljø hos modersoen. Nord. Vet.-Med. 1962, 14, 770-779.

Ludvigsen, J.: Unders $\varnothing$ gelser over nysesyge og dens årsager. 319. Beretn. Fors $\varnothing$ gslab., Kbh. 1960.

Majno, G. \& E. Rouiller: Die alkalische Phosphatase in der Biologie des Knochengewebes. Virchows Arch. path. Anat. 1951, 321, $1-60$.

Miller, E. R., D. E. Ullrey, C. L. Zutaut, B. V. Baltzer, D. A. Schmidt, $J$. A. Hoefer \& R. W. Luecke: Calcium requirement in the baby pig. J. Nutr. 1962, 77, 7-17.

Miller, E. R., D. E. Ullrey, C. L. Zutaut, B. V. Baltzer, D. A. Schmidt, J. A. Hoefer \& R. W. Luecke: Phosphorus requirement of the baby pig. J. Nutr. 1964a, 82, 34-40.

Miller, E. R., D. E. Ullrey, C. L. Zutaut, J. A. Hoefer \& R. W. Luecke: Mineral balance studies with the baby pig: Effects of dietary phosphorus level upon calcium and phosphorus balance. J. Nutr. $1964 \mathrm{~b}, 82,111-114$.

Miller, E. R., D. E. Ullrey, C. L. Zutaut, B. V. Baltzer, D. A. Schmidt, B. H. Vincent, J. A. Hoefer \& R. W. Luecke: Vitamin $\mathrm{D}_{2}$ requirement of the baby pig. J. Nutr. 1964c, 83, 140-148.

Miller, E. R., D. E. Ullrey, C. L. Zutaut, J. A. Hoefer \& R. L. Luecke: Comparisons of casein and soy protein upon mineral balance 
and vitamin $D_{2}$ requirement of the baby pig. J. Nutr. 1965, 85, $347-354$.

National Research Council, Nat. Acad. Sci.: Nutrient requirements of swine. 5th rev. Ed. 1964.

Nieberle, $K . \&$ P. Cohrs: Lehrbuch der speziellen pathologischen Anatomie der Haustiere. 4. Aufl. Gustav Fischer Verlag, Stuttgart 1962, $1067 \mathrm{pp}$.

Pallaske, G.: Pathologische Histologie. 2. Aufl. Veb Gustav Fischer Verlag, Jena 1960, 457 pp.

Pedersen, J. G. A.: Experimentel rakitis hos svin. Betydningen af foderets indhold af fytin og fytase. 193. Beretn. Fors $\varnothing$ gslab., Kbh. 1940 .

Pullar, E. M.: Mineral deficiencies in pigs. Bone ash estimations as a diagnostic aid in rickets and osteomalacia. Aust. vet. J. 1960, $36,31-45$.

Recklinghausen, F. von: Uber Rachitis und Osteomalacie. Jena, Fischer, 1910. (Cited from Brown et al. 1966).

Ringbom, A., G. Pensar \& E. Wänninen: A complexiometric titration method for determining calcium in the presence of magnesium. Analytica chim. Acta 1958, 19, 525-531.

Rutledge, E. A., L. E. Hanson \& R. J. Meade: A study of the calcium requirements of pigs weaned at three weeks of age. J. Animal Sci. 1961, 20, 243-245.

Schofield, F. W. \& T. L. Jones: The pathology and bacteriology of infectious atrophic rhinitis in swine. J. Amer. vet. med. Ass. 1950, $116,120-123$.

Simesen, M. G.: Calcium, inorganic phosphorus, and magnesium metabolism in health and disease. In, Cornelius \& Kaneko: Clinical biochemistry of domestic animals. Academic Press, New York and London 1963, 441-498.

Switzer, W. P.: Infectious atrophic rhinitis. In, H. W. Dunne: Diseases of swine. The Iowa State University Press, Ames, Iowa 1964, $675-694$.

Vadla, E., T. Homb, M. Husby \& K. Breirem: Standardkraftfórblandinger til svin. 81. Beretn. Norges Landbr.Høgsk., Fóringsfors. 1957.

Zeiss-Opton: Klinische Photometrie. 3. Aufl. Stuttgart 1951, 124 pp.

Zimmermann, D. R., V. C. Speer, V. W. Hays \& D. V. Catron: Effect of calcium and phosphorus levels on baby pig performance. J. Animal Sci. 1963, 22, 658-661.

\section{SUMMARY}

Thirty-two pigs were divided into 8 groups in an experiment to study the effect of various levels of calcium, phosphorus and vitamin $D$ in the feed on weight gain, feed conversion, calcium, inorganic phosphorus and alkaline phosphatase in serum, ash content of the bones and the health of the pigs.

Deficiency of vitamin $D$ caused various degrees of rickets, and some of the animals fed on a diet with a low calcium-phosphorus ratio 
died in hypocalcemic convulsions. Vitamin D deficiency caused a fall in serum calcium, followed by an increase in alkaline phosphatase.

The animals on a diet deficient in vitamin $D$ and with a low calcium-phosphorus ratio had a poorer weight gain, decreased feed conversion efficiency and lower ash content of the bones than the animals on diets with an optimal composition.

Various degrees of bone resorption were observed by histological examination of the turbinates from animals on diets with an unfavourable calcium-phosphorus ratio or deficient in vitamin $D$. The bone resorption was caused by socalled pericytic osteolysis. Signs of osteodystrophia fibrosa were also found. Neither macroscopic nor histological signs of atrophic rhinitis were seen.

In some cases of spontaneous atrophic rhinitis from pigs outside the experiment pericytic osteolysis of the turbinates was also shown. It is concluded that this form of bone resorption may occur simultaneously with atrophic rhinitis when the diet is deficient in vitamin $D$ or when the calcium-phosphorus ratio is unfavorable.

\section{ZUSAMMENFASSUNG}

Die Wirkung verschiedener Mengen Kalzium, Phosphor und D-Vitamin im Futter von Mastschweinen, insbesonders mit Hinblick auf die Schnüffelkrankheit.

32 Schweine auf 8 Gruppen verteilt nahmen an einem Versuch teil, dessen Ziel es war die Wirkung von verschiedenen Mengen Kalzium, Phosphor und D-Vitamin im Futter auf Zuwachs, Futterverbrauch, Kalzium, Phosphor und alkalische Phosphatase im Serum, den Aschegehalt in den Knochen sowie den Einfluss auf den Gesundheitszustand der Tiere zu untersuchen.

Ein Mangel an D-Vitamin führte zu verschiedenen schweren Formen von Rachitis. Ein Teil der Tiere, die eine Diät mit niedrigem $\mathrm{Ca} / \mathrm{P}$-Gehalt erhielten, starben an hypokalzemischen Krämpfen. Weiter verursachte ein Mangel an D-Vitamin einen Fall im Serum-Kalzium und eine Steigerung der alkalischen Phosphatase.

Histologisch wurden variierende Grade einer Knochenresorption im Concha bei einem ungünstigen $\mathrm{Ca} / \mathrm{P}$-Verhältnis wie bei einem D-Vitaminmangel festgestellt. Diese war von einer sogenannten perizytären Osteolyse verursacht. Ebenfalls erwiesen sich Zeichen von Osteodystrofia fibrosa.

Makroskopisch sah man keine Zeichen einer Atrophie, und auch histologisch bestand nicht dasselbe Bild wie bei der Schnüffelkrankheit.

Bei einer Zahl spontanen Fällen der Schnüffelkrankheit wurde ebenfalls perizytäre Osteolyse im Concha festgestellt. Es wird deshalb angenommen, dass diese Art von Knochenresorption parallel mit der Schnüffelkrankheit auftreten kann, falls der D-Vitamin Bedarf mangelhaft eingedeckt ist oder wo das Ca/P-Verhältnis im Futter ungünstig ist. 


\section{SAMMENDRAG}

Virkningen af ulike mengder kalsium, fosfor og vitamin $D$ i fóret til slaktegriser, spesielt med henblikk på nysesjuke.

32 griser fordelt på 8 grupper inngikk i et fors $\varnothing k$ der en tok sikte på å unders $\varnothing$ ke virkningen av forskjellige nivåer av kalsium, fosfor og vitamin D i fóret på tilvekst, fórforbruk, kalsium, fosfor og alkalisk fosfatase i serum, askeinnholdet i knoklene samt innvirkning på dyrenes helsetilstand.

Mangel på vitamin D førte til ulike grader av rakitt, og en del av dyrene på dietter med lavt $\mathrm{Ca} / \mathrm{P}$-forhold $\mathrm{d} \phi \mathrm{de}$ av hypokalsemiske kramper. Videre ga vitamin D-mangel fall i serum-kalsium og stigning i alkalisk fosfatase.

Fórutnyttelse, tilvekst og askeinnhold i knoklene var lavere ved mangel på vitamin $\mathrm{D}$ og ved et skjevt $\mathrm{Ca} / \mathrm{P}$-forhold $\mathrm{i}$ fóret, enn når kalsium, fosfor og vitamin D-innholdet i fóret var optimalt.

Histologisk ble det påvist varierende grader av beinresorpsion i concha ved et skjevt $\mathrm{Ca} / \mathrm{P}$-forhold og ved vitamin D-mangel. Denne var forårsaket av såkalt pericyttær osteolyse. Det var også tegn på osteodystrofia fibrosa.

Makroskopisk var det ingen tegn på atrofi, og histologisk fantes heller ikke det samme bilde som ved nysesjuke.

Fra en del spontantilfelle av nysesjuke ble det også funnet pericyttær osteolyse av concha. En antar derfor, at denne form for beinresorpsjon kan opptre parallelt med nysesjuke dersom dekningen av vitamin D-behovet er mangelfull, eller hvis $\mathrm{Ca} / \mathrm{P}$-forholdet $\mathrm{i}$ fóret er ugunstig.

(Received October 4, 1967). 